\title{
The Relationship between Political Participation Intentions of Adolescents and a Participatory Democratic Climate at school in 35 countries.
}

\section{Quintelier, Ellen}

Hooghe, Marc

Oxford Review of Education (forthcoming)

\begin{abstract}
In the literature it is expected that a participatory democratic climate is associated with civic and political engagement intentions of adolescents. In this paper we use a three level multilevel analysis to explore these relations: the individual, school and country level. Using data from the International Civic and Citizenship Education Study (2009) from 35 countries, we find that the individual student perception of a participatory democratic climate, especially openness in classroom discussions at the individual level, is positively associated with intended political participation. The teacher's and principals' perception of the participatory climate, on the other hand, were not related to the intention to participate. In this discussion we offer some ideas on how this individual level effect might be explained.
\end{abstract}

\section{Introduction}

In most democratic political systems, it is expected that the education system will contribute to the establishment of democratic citizenship. At school, pupils acquire knowledge about the functioning of the political system, it is hoped that they will develop and internalize democratic values and norms, and that they will engage in various forms of active and democratic citizenship (Youniss and Levine 2009). In most of the literature it now has become accepted that participation is a key defining element of contemporary notions of democracy (Norris 2011). Partly as a result of the 
widespread concern about an alleged decline of civic engagement, around the globe countries and education systems have stepped up their efforts with regard to civic education (Youniss 2011). While education systems are being confronted with high expectations, it is less clear how exactly they (can) contribute to the formation of democratic citizenship. While in some of the older literature, cognitive elements of citizenship and feelings of patriotism were emphasized, in the current literature it has become customary to stress the impact of an open classroom climate and a democratic functioning of the school itself (Hahn 1998; Hess 2009; Torney-Purta et al. 2001; Torney-Purta 2002). In this manner, the old idea of Dewey (1913) that schools themselves should function as democratic communities in order to prepare their pupils for their future role in democratic societies, is revived again.

Critics however, would argue that schools are ill-equipped to respond to this expectation. Even when schools manage to function as a democratic community, schools often have no other option than to comply with curriculum requirements. Furthermore pupils inevitably will also pick up the messages that are being sent out by the political system itself. While their teachers at school might tell them how wonderful democracy is, their parents and their day-to-day interactions with reality might tell them that in practice the political system of their country does not really reward their engagement. Within participation research, it is generally assumed that some countries offer a more open political opportunity structure for participation than others (Tarrow 2003). It is important therefore that studies on the effect of schools on democratic citizenship should be conducted in a comparative manner, in order to ascertain what are the effects of school experiences in different countries. In 2009, the International Association for the Evaluation of Educational Achievement (IEA) conducted a major international study 
on the effects of civic education in 35 countries, with a total of 109,784 respondents (International Civic and Citizenship Education Study - ICCS, 2009). Furthermore, the study included information about the perception of a participatory democratic climate, and this information was obtained not only from pupils but also from teachers and school principals. This unique and very rich data set thus far remains largely unexplored in comparative educational research, although it includes all the information that is required to investigate the effects of school experiences and perceptions of school climate in a reliable manner. In this article, our goal is to ascertain whether the perception of a participatory democratic climate at school is associated with the intention to participate in political life.

We first briefly review the literature on the effects of school climate, before presenting data and methods. Subsequently we investigate whether both curricular as well as interaction climate characteristics of schools are related with the propensity to participate.

\section{Review of the literature}

Since the turn of the century, there is clearly a renewed interest for the study of (the effects of civic education at schools. While 'developmental science has until recently ignored civic engagement, focusing overwhelmingly on cognitive and social development leading to work or family formation' (Sherrod et al. 2010: 2), political socialization studies have long neglected political participation outcomes as well (Marsh 1971). Non-cognitive outcomes of school experiences can included attitudes like trust or tolerance, feelings of efficacy, or the intention to participate in civic life (Hahn 1998; 
Hess 2009; Torney-Purta et al. 2008; Westheimer and Kahne 2004). In this article, we focus on a behavioral outcome of school experiences: the intention to participate in different forms of civic and political engagement. Since adolescents do not have access to the full range of political participation opportunities yet, their intention to take part in these forms later on can be seen as the closest proxy-indicator that is available to measure this outcome (Benton et al. 2009). Our aim is to arrive at a comprehensive study of the intention to participate, using the three level structure of the ICCS data. The availability of these data means we can distinguish three different levels of analysis: the individual pupil, the school and the country level. While earlier studies on the effects of school experiences mainly focused on single country case studies (with the exception of those that used the previous IEA studies and the Hahn (1998) study), we can now develop a broad comparative perspective, using data from almost all countries that were included in the ICCS study (Campbell 2006a; Galston 2007; Jennings 2007; Niemi and Junn 1998; Torney-Purta et al. 2001; Torney-Purta et al. 2007). ${ }^{1}$

It is assumed that if schools offer opportunities for political participation and involvement, adolescents will use these opportunities, thus leading to higher participation levels. On the school level, this means we focus on the perception of a participatory democratic climate. It is expected that when students perceive the interaction climate at school as allowing or even encouraging their engagement, they will also use this opportunity. In the ICCS questionnaire, students were asked about their perception of the openness for classroom debate, for having influence on school decisions, and the quality of personal relationships. Jointly, we can label these three scales as a 'participatory democratic climate', as these three measures go beyond the narrower measurement scale for an open classroom climate (Torney-Purta et al. 1975). 


\section{Participatory democratic climate}

While the older research focused strongly on cognitive learning strategies and on cognitive outcomes of civic education, in the more recent literature, the perception of the interaction climate at school has been highlighted (Barber and Torney-Purta 2009; Hahn 1998). The notion of an open classroom climate has played an important role in this line of research. Most often this refers to 'classrooms as places to investigate issues and explore their opinions and those of their peers' or to 'independence of opinion encouraged in the classroom' (Ehman 1970; Hahn 1998; Torney-Purta et al. 1975; Torney-Purta et al. 2001: 137-38). Campbell (2008: 440) uses a more restricted definition and uses the concept to refer to 'discussion of political issues'. Ichilov (2003: 653), finally, defines an open classroom climate as 'students' feeling that they can freely participate and express themselves in a supportive environment'. Although these definitions differ slightly, the focus of most definitions is on the possibility to discuss freely and to develop a personal opinion on politics and other issues in class. Previously, open classroom climate has been related to political engagement (Campbell 2008), political trust and interest (Ehman 1980), tolerant attitudes and support for equality (Hahn 1998), gender and politics (Barber and Torney-Purta 2009) and human rights (Torney-Purta et al. 2008).

In the ICCS questionnaire the perception of an open classroom climate is not measured in the conventional manner, but a number of related scales are used and can be brought together. First, pupils were asked about whether classroom discussions can be conducted in an open manner. Second, they were asked how much influence they have on the way their school is being run. Third, they received questions about the quality of the interaction with their teachers. As all three scales refer to the perception of the 
interaction at school, jointly we can refer to them as the perception of a participatory democratic climate. It has to be noted, however, that throughout this article, we always will talk about the perception of such a climate, as not everyone who is involved in the school interaction will have exactly the same perception. Our main independent variable, the perception of a participatory democratic climate at school thus is clearly related to the traditional operationalisation of an open classroom climate, but simultaneously it is also much broader than this concept.

Within the literature, the general expectation is that an open, democratic and participatory school climate will be positively associated with the propensity to engage in various form of civic participation (Campbell et al. 2006). A more participatory, interactive and less authoritarian school climate was found to be associated with more democratic and tolerant political attitudes (Flanagan et al. 2007; Gimpel et al. 2003; Gniewosz et al. 2009; Jaros 1973; Torney-Purta et al. 2007; Whiteley 2005). ${ }^{2}$ The openness for participation and democratic deliberation at school allows pupils to have their say on school decisions and it increases the participation potential of young people (Hess 2009; Quintelier 2010; Torney-Purta 2002; Torney-Purta and Vermeer 2006). Political discussion and debate at school is positively correlated with political knowledge, trust, civic skills, political efficacy, tolerance, intention to engage in political participation and attention to politics, while it should also be associated with feelings of political empowerment (Almond and Verba 1963; Gibson and Levine 2003; Niemi and Junn 1998; Torney-Purta et al. 2001). Although the causal mechanism is far from clear, one can speculate that because of the discussions, politics is rendered more salient for adolescents, or it might also stimulate the process of forming their own political identities and preferences (Campbell 2006b). 
Thus far, it remains to be investigated whether the perception of a participatory democratic school climate is associated with civic education outcomes. In this article, we focus on one specific outcome: the intention to participate in political life. Given the fact that we focus on adolescents, we cannot measure yet real participation levels as the 14 year olds that were sampled in the ICCS study do not have the means yet to fully participate in political life. Although we do not expect that the intention to participate equals future participation, at least we assume a strong positive correlation between intention and actual behavior (Hooghe and Wilkenfeld 2008). Therefore, we focus on the intention to participate as the main dependent variable. This review of the literature therefore leads to our main research question: Is the perception of a participatory democratic climate at school correlated with the intention for future political participation among pupils?

\section{Data and methods}

The data that will be used are derived from the International Civic and Citizenship Education Study (ICCS) 2009. These data compare the civic attitudes of more than 109,784 14-year old students in 35 countries. This international survey has been funded by the educational authorities of the participating countries, the UNESCO Education Sector, the European Commission and the Inter-American Development Bank (for more information see: http://iccs.acer.edu.au). The international sample design used for ICCS was a stratified two-stage probability. During the first stage, schools were sampled with probability proportional to size. During the second stage, one intact class of target-grade students and a fixed number of target-grade teachers were randomly selected (Schulz et al. 2011: 59). The questionnaire was first developed in English, and then translated by 
countries to their languages of instruction. All national instruments were subject to a stringent international verification process that included a thorough review of the adaptations, translation, and layout (Schulz et al. 2011: Chapter 5). As the survey was organized by the educational authorities themselves, in most countries this resulted in very high response rates: only two countries had school response rates lower than 70 percent (Schulz et al. 2010). Missing values on items were substituted with means (for continuous variables) and medians (for categorical variables) by the ICCS coordination organization,

\section{Dependent variable}

It is clear that political participation should not be regarded as a one-dimensional phenomenon, as earlier studies have demonstrated strong differences with regard to the characteristics of institutionalized and non-institutionalized forms of participation (Dalton 2008). While institutionalized forms of participation refer to elite-initiated forms of engagement, non-institutionalized forms usually take place outside the context of electoral politics (Ainley and Schulz 2011). This distinction is reflected in four different measurement scales for future participation. The first scale is the students' expected participation in future legal protest. It includes six items about whether the respondent would take part in these protest activities in the future: writing a letter to a newspaper, wearing a badge or a t-shirt expressing your opinion, contacting an elected representative, taking part in a peaceful march or rally, collecting signatures for a petition, and choosing not to buy certain products.

The second scale is the students' intended electoral participation, and it consists of three items: voting in local and national elections and obtaining information about candidates 
before voting in an election. The third scale measures students' expected adult participation in activities related to political parties, referred to as participation in political activities. This scale has four indicators, namely 'help a candidate or party during an election campaign', 'join a political party', 'join a trade union' and 'stand as a candidate in local elections'. The fourth scale is the students' expected future informal political participation. Here too we have four items: talking to others about your views on political and social issues, writing to a newspaper about political and social issues, contributing to an online discussion forum about social and political issues and joining an organization for a political or social cause. All scales were created with a mean of 50 and a standard deviation of 10 , to make the scales comparable and easy to interpret. We will rely on the scales that are provided by ACER, the ICCS coordination organization (Ainley and Schulz 2011; Schulz et al. 2011). The advantage of these scales is that they are tested on onedimensionality (using confirmatory factor analysis) and item response (Rasch-)modeling to produce cross-nationally equivalent scales across all countries taking part in ICCS 2009.

\section{Individual level independent variables}

The main independent variable of interest in our analysis is the perception of a participatory democratic climate. With this concept we refer to three different measurement scales. A first measure is the students' perception of open discussion opportunities in the classroom discussions (6 items, with as most characteristic item: "teachers encourage students to express their opinions"). This operationalisation is related most strongly to the definition of an open classroom climate provided by Ehman (1970: 2). Additionally, we also include students' perceptions of influence on decisions about school (6 items, e.g., 'how much is your opinion taken into account when decisions 
are made about classroom rules') and of student-teacher relations at school (5 items, e.g., 'most of my teachers treat me fairly') to investigate how strongly students have the feeling that their opinion is being taken into account in school governance.

Furthermore, we also included several control variables at the individual level: gender, socio-economic status, as operationalised by the number of estimated books at home (also referred to as literacy resources of the home) and the expected years of further education, self-efficacy, trust in civic institutions, internal political efficacy, interest in politics and social issues, the occurrence of political discussion outside school, civic participation in the wider community, and civic knowledge, all factors that are known to influence political participation (Eccles and Roeser 2011; Gimpel et al. 2003; Kahne and Sporte 2008; McFarland and Thomas 2006; Verba et al. 1995). The descriptives of all the variables used in the analysis can be found in Appendix 1 and the exact wording of all control variables in Appendix 4.

\section{The school context}

An unique feature of the ICCS survey is that also the teachers and principal of each school were also surveyed on their perception of the interaction climate in their school. First they were asked to rate the student interactions (e.g. in your opinion, how many of your students get on well with their classmates?) and student's influence on decisions about school (e.g. at this school, how much are students' opinions taken into account when decisions are made?). The specific items of these teacher and principals' questionnaires are presented in Appendix 3. It has to be noted that while the questionnaire for the pupils is not identical to the questionnaire for teacher and principals, they do have in common that all of them refer to the interaction climate 
within a school. We aggregated the teacher data (mean values) at the school level because it was impossible to link specific teachers to specific classes. Our assumption is that the answers of the teachers reflect a perception of the general culture at their school, and that they are not specifically tied to one class within that school.

Additionally, also the principals of the schools were surveyed about their perception of students' influence on decisions about school policy. These items are similar to the ones presented to the teachers. Finally, we included a limited number of school characteristics: school autonomy, school size and student-teacher ratio because one could expect that it will be easier to obtain a participatory democratic climate and higher levels of participation in smaller schools or schools with smaller classes. The fewer students there are in class or at school, the more likely they are to be asked for their opinion (Lay 2007; Lindsay 1984).

As the ICSS data clearly have a nested three-level structure: pupils in schools in countries, we will use multilevel analyses to analyze the data (Hox 2002). For the country level no variables are included, as we do not have any specific hypothesis about the effects of this level.

\section{Results}

Given the complexity of the data and the models, we develop the model in 2 steps: first we present the correlations between the different participatory democratic climate indicators, then we present the full multilevel regression results, in which we include individual level-variables and school level variables. 
First, we focus on the correlations, and it has to be remembered that this concept was measured at three different level (student, class \& school). For Table 1, we aggregated all measures at the school level so that we have for each school a mean perception of the participatory democratic climate of the students and teachers at school. We find that students' perceptions of openness in classroom discussions correlates strongly with their perception of the student-teacher relationships at school $(0.324 ; \mathrm{p}<0.001)$. However, it correlates only modestly with their perception of their involvement in decisions about school $(0.113 ; \mathrm{p}<0.001)$. The highest correlation at the student-level can be found between the perceived quality of the student-teacher relationships and the perceived influence on decisions about school $(0.597 ; \mathrm{p}<0.001)$. However, what is of most interest to us, is the correlation between the perception of students on the one hand, and teachers and principals on the other. In line with was earlier found by Ehman (1970), it can be noted that these correlations are very weak. Apparently, students, teachers and principals do not necessarily agree on the characteristics of the interaction climate at their schools. The scale on openness in classroom discussions has a limited correlation with the scores of the teachers and principals on the influence of students on school policy. We find somewhat higher correlations (about .30) between the students' and the teachers' perception of influence on school policy; the teachers' and principals' perception of influence on school policy; and the students' perception of student-teacher relationship and the teachers' perception of the classroom interaction. So overall, we find that the perception of students, teachers and principals can be substantially different (i.e., has low correlations) if we compare rather similar measures. This leads to the question what matters for the intention to participate among students: does it matter how they experience the climate at school, or is it more important how teachers and/or schools principals perceive this climate? Ehman (1970) suggests that the 
student-reported data should be preferred. He explains this by the fact that teachers who find freedom of expression very important, are more likely to underestimate students' voice in the classroom whereas teachers who find this not that important, are more likely to give moderate scores. This leads to less variance in the teachers' ratings, and consequently to lower correlations between the students' and teachers' perception. 
Table 1. Correlation between measurements of participatory democratic climate at school

\begin{tabular}{|c|c|c|c|c|c|c|c|}
\hline & & \multicolumn{3}{|c|}{ Students' perceptions of ... } & \multicolumn{2}{|c|}{ Teachers perceptions of ... } & \multirow{2}{*}{$\begin{array}{c}\text { Principals' } \\
\text { perceptions of ... } \\
\text { Students' } \\
\text { influence on } \\
\text { decisions about } \\
\text { school }\end{array}$} \\
\hline & & $\begin{array}{l}\text { Openness in } \\
\text { classroom } \\
\text { discussions }\end{array}$ & $\begin{array}{c}\text { Influence on } \\
\text { decisions about } \\
\text { school }\end{array}$ & $\begin{array}{l}\text { Student-teacher } \\
\text { relationships at } \\
\text { school }\end{array}$ & $\begin{array}{l}\text { influence on } \\
\text { decisions about } \\
\text { school }\end{array}$ & $\begin{array}{l}\text { Classroom climate } \\
\text { of student } \\
\text { relationships }\end{array}$ & \\
\hline \multirow[t]{3}{*}{$\begin{array}{l}\text { Students' } \\
\text { perceptions } \\
\text { of ... }\end{array}$} & $\begin{array}{l}\text { Openness in } \\
\text { classroom } \\
\text { discussions }\end{array}$ & 1 & & & & & \\
\hline & $\begin{array}{c}\text { Influence on } \\
\text { decisions about } \\
\text { school }\end{array}$ & $0.113^{* * *}$ & 1 & & & & \\
\hline & $\begin{array}{l}\text { Student-teacher } \\
\text { relationships at } \\
\text { school }\end{array}$ & $0.324^{* * *}$ & $0.597^{* * *}$ & 1 & & & \\
\hline \multirow[t]{2}{*}{$\begin{array}{l}\text { Teachers' } \\
\text { perceptions } \\
\text { of ... }\end{array}$} & $\begin{array}{c}\text { Student's influence } \\
\text { on decisions about } \\
\text { school }\end{array}$ & $0.015 \mathrm{~ns}$ & $0.368^{* * *}$ & $0.280^{* * *}$ & 1 & & \\
\hline & $\begin{array}{l}\text { Classroom climate } \\
\text { of student } \\
\text { relationships }\end{array}$ & $0.216^{* * *}$ & $0.212^{* * *}$ & $0.387^{* * *}$ & $0.221^{* * *}$ & 1 & \\
\hline $\begin{array}{l}\text { Principals' } \\
\text { perceptions } \\
\text { of ... }\end{array}$ & $\begin{array}{c}\text { Students' influence } \\
\text { on decisions about } \\
\text { school }\end{array}$ & $0.040 * *$ & $0.160^{* * *}$ & $0.101^{* * *}$ & $0.389 * * *$ & $0.070^{* * *}$ & 1 \\
\hline
\end{tabular}

Entries are Pearson correlations between participatory democratic climate, all aggregated at the school level. Sign. ns: $p>0.05$; ${ }^{*}$ p $<.05$; $* * \mathrm{p}:<.01 . ; * * * \mathrm{p}:<.001$. 
After this first exploration, we proceed to the multilevel analyses. Overall, we find a substantial level of intraclass correlation. Even in the null models (see appendix), we find an intraclass correlation of 10 to 13 percent at the school level and 6 to 9 percent at the country level. This means that there is a substantial correlation between the students' level of intended political participation at the same school and in the same country. Most of the observed difference, however, can be found at the individual level. This also explains why the individual level variables have much stronger effects than the school level variables. These findings are similar to the ones found by Hess (2009) and Hahn (1998) who both have shown that the open classroom climate can be perceived differently by individuals in the same class and that therefore it is important to focus on individual level perceptions and measurements.

First, looking at the control variables, we find that boys are more likely to have the intention to participate in electoral politics and political activities. The indicators about the estimated number of books at home and the expected years of further education only have a limited effect: The more books at home, the higher the intention for legal protest and electoral participation and the higher the expected years of education, the more intention for electoral participation and participation in political activities participation in political activities. The effects of the other control variables are most often in the expected direction: the higher the levels of self-efficacy, trust in civic institutions, internal political efficacy, interest in politics and social issues, the more political discussion outside school, civic participation in the wider community and civic knowledge, the higher the intention for political participation. Only for civic knowledge, two negative effects can be found. Although civic knowledge is positively associated with the intention for legal protest and electoral participation, it is negatively associated with 
informal intended political participation and intended participation in political activities such as party membership and candidacy. ${ }^{3}$

However, what is mainly of interest in the current analysis, is the relation between the perception of a participatory democratic climate on the intention for political participation. We find that all three measures of the individual perception of a participatory democratic climate are positively associated with the future likelihood of political participation. Students who perceive classroom discussions to be open, are more likely to participate in legal protest, electoral and informal political participation in the future. The perception of having an influence on decisions about school is associated with more future participation in political activities such as party membership and candidacy and informal political participation, but less informal political participation. The results of the perception of a positive relation between students and teachers is associated with more negative results for political participation: the better the perceived relationship between teachers and students, the lower the intention for legal protest, participation in political activities and informal political participation. However, a positive evaluation of student-teacher relations is associated with a stronger intention to participate in electoral behaviour.

We also include information about the perceptions of teacher and school principals. Most of these associations are non-significant. We only find significant effects of the teachers' perception of the quality of student relationships (on intended electoral participation) and the teachers' perception of student's influence on school policy (on intended informal political participation). ${ }^{4}$ The other six effects are not significant. For the principals' perception of student's influence on school decisions, we found even no 
positive effects. Whether or not teachers and principals rate their school as 'democratic' or 'participatory', therefore does not seem to matter in this regard. Furthermore, if we aggregate the students' perception of the participatory democratic climate at the school level, we find the same not statistically significant results (see Appendix 2). Only for the intention to participate in political activities, we find an effect, but this association is negative. As we have already seen in Table 1, students, teachers and principals do not agree in their assessment about the level of the participatory democratic climate at school. However, what seems to matter most for intended political participation is the perception by the students themselves (Ehman 1970). So apparently, if students feel that they are heard at school, they will be more likely to say that they will participate in politics in the future.

In the analysis we also include other school level variables. We find that in schools with a higher student-teacher ratio (i.e. a class with more students per teacher) we find a greater likelihood for intended future political participation in protesting and other political activities. This might be because these schools on average have fewer financial means (Schulz et al. 2011, Ch. 12) and students want to protest against this, or and more likely, because larger classes allow more diverse opinions and interactions leading to more intentions for future political participation. A more limited school autonomy, on the other hand, leads to less informal intended political participation and a larger school size to less participation in political activities such as party membership and candidacy. For the other variables, we found no significant effects. 
Table 2. Individual and School Level effects on Intention to Participate

\begin{tabular}{|c|c|c|c|c|c|c|c|c|c|c|c|c|c|}
\hline \multirow{2}{*}{\multicolumn{2}{|c|}{ Students' expected adult ... }} & \multicolumn{3}{|c|}{ Legal protest } & \multicolumn{3}{|c|}{ Electoral participation } & \multicolumn{3}{|c|}{$\begin{array}{c}\text { Participation in } \\
\text { political activities }\end{array}$} & \multicolumn{3}{|c|}{$\begin{array}{c}\text { Informal political } \\
\text { participation }\end{array}$} \\
\hline & & $\mathrm{B}$ & SD & Sig. & $\mathrm{B}$ & SD & Sig. & $\mathrm{B}$ & $\mathrm{SD}$ & Sig. & $\mathrm{B}$ & SD & Sig. \\
\hline \multirow{17}{*}{ 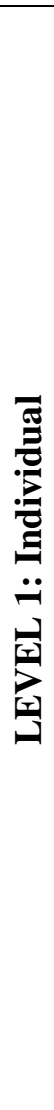 } & Constant & 50.042 & 0.373 & $* * *$ & 49.942 & 0.406 & $* * *$ & 50.206 & 0.235 & $* * *$ & 50.335 & 0.235 & $* * *$ \\
\hline & Background variables & & & & & & & & & & & & \\
\hline & Gender (1=girl) & 0.027 & 0.209 & ns & -0.070 & 0.089 & ns & -1.009 & 0.125 & $* * *$ & -0.166 & 0.120 & ns \\
\hline & Number of books at home & 0.135 & 0.028 & $* * *$ & 0.153 & 0.045 & $* * *$ & -0.002 & 0.029 & ns & 0.051 & 0.027 & ns \\
\hline & Expected years of further education & -0.028 & 0.019 & ns & 0.191 & 0.018 & $* * *$ & 0.031 & 0.016 & $*$ & 0.010 & 0.017 & ns \\
\hline & Control variables: students' ... & & & & & & & & & & & & \\
\hline & Citizenship self-efficacy & 0.328 & 0.013 & $* * *$ & 0.133 & 0.007 & $* * *$ & 0.209 & 0.010 & $* * *$ & 0.280 & 0.011 & $* * *$ \\
\hline & Trust in civic institutions & 0.067 & 0.006 & $* * *$ & 0.160 & 0.010 & $* * *$ & 0.155 & 0.006 & $* * *$ & 0.075 & 0.006 & $* * *$ \\
\hline & Sense of internal political efficacy & 0.103 & 0.012 & $* * *$ & 0.122 & 0.008 & $* * *$ & 0.176 & 0.008 & $* * *$ & 0.176 & 0.010 & $* * *$ \\
\hline & Interest in politics and social issues & 0.083 & 0.006 & $* * *$ & 0.125 & 0.008 & $* * *$ & 0.120 & 0.006 & $* * *$ & 0.169 & 0.008 & $* * *$ \\
\hline & Discussion of political issues outside school & 0.013 & 0.004 & $* * *$ & 0.017 & 0.004 & $* * *$ & -0.003 & 0.003 & ns & 0.055 & 0.003 & $* * *$ \\
\hline & Civic knowledge & 0.010 & 0.001 & $* * *$ & 0.028 & 0.001 & $* * *$ & -0.015 & 0.001 & $* * *$ & -0.004 & 0.001 & $* * *$ \\
\hline & Civic participation in the community & 0.096 & 0.005 & $* * *$ & 0.020 & 0.005 & $* * *$ & 0.064 & 0.004 & $* * *$ & 0.072 & 0.003 & $* * *$ \\
\hline & Open classr. clim.: Students' perceptions of & & & & & & & & & & & & \\
\hline & Openness in classroom discussions & 0.023 & 0.005 & $* * *$ & 0.030 & 0.005 & $* * *$ & -0.001 & 0.006 & ns & 0.027 & 0.004 & $* * *$ \\
\hline & Influence on decisions about school & 0.000 & 0.008 & ns & -0.017 & 0.005 & $* *$ & 0.017 & 0.006 & $* *$ & 0.022 & 0.005 & $* * *$ \\
\hline & Student-teacher relationships at school & -0.013 & 0.006 & * & 0.046 & 0.006 & $* * *$ & -0.020 & 0.004 & $* * *$ & -0.014 & 0.004 & $* * *$ \\
\hline
\end{tabular}




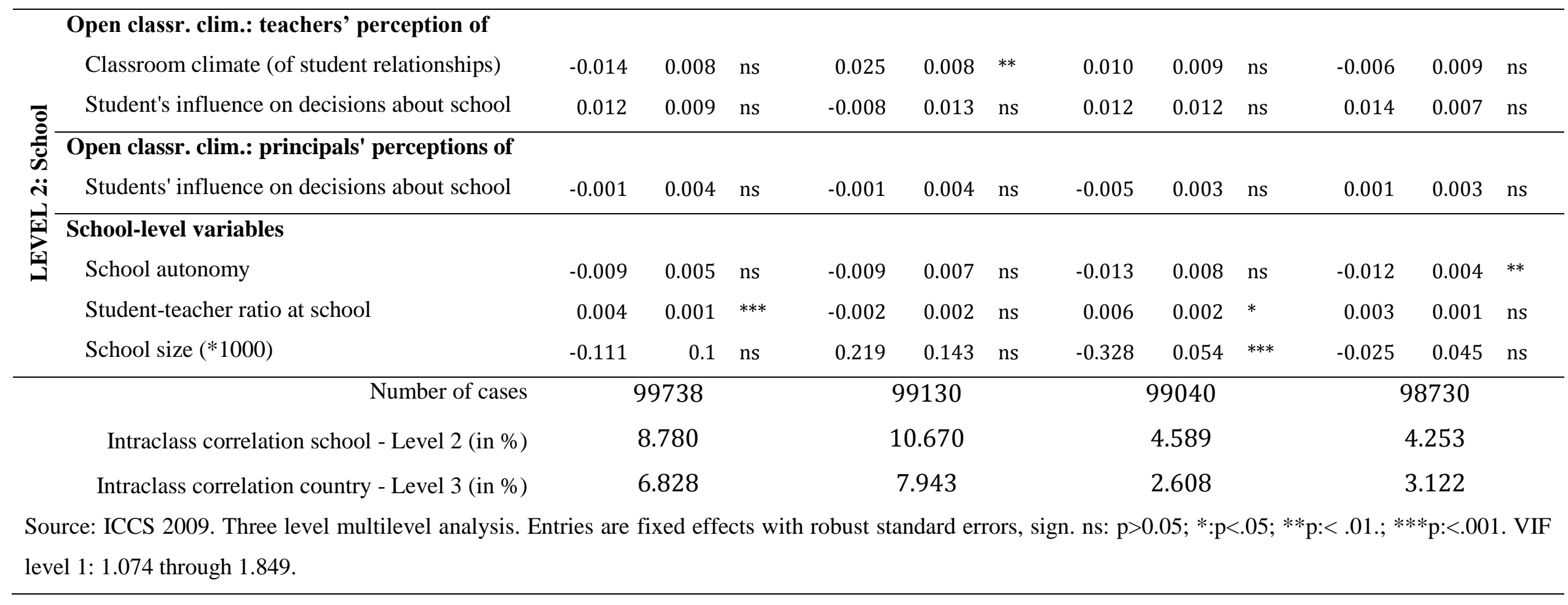




\section{Discussion}

In the literature we find high expectations about the long term effect of experiences with a participatory democratic climate at school. This type of school culture is expected to have an effect on civic and political attitudes, including the intention to participate in politics in different ways. In this article, we analysed the effect of school characteristics on the intention to participate among 109,000 14-year old adolescents from 35 countries. This large scale data set allowed us to investigate the impact of the perception of the school climate on the likelihood that students think they will participate in political life. The results indeed suggest that the students' perception of a participatory democratic climate plays an important role in this regard. Adolescents who perceive an open climate for classroom discussion, clearly are more likely to expect to participate later on in their life. As such, this analysis confirms that schools play a role in stimulating the intention to participate in politics predominantly by functioning as a democratic community or 'schools of democracy', exactly in the way Dewey stated in his writings. Also other measures of the individual perception of a participatory democratic climate like the influence on decisions about school and the student-teacher relationships at school are positively associated with the intention to participate in politics in the future.

In the analyses, we distinguished between four types of political participation: legal protest, electoral participation, participation in political activities (such as party membership and candidacy) and informal political participation. Although the main findings are similar for each type of political participation (the student's perception of a participatory climate matters while the perception of the principals and the teachers do not), there are slight differences for each type of political participation. Legal protest is 
positively associated with openness in classroom discussion and negatively with good student-relationships at school. Electoral participation is positively associated with openness in classroom discussion and good student-relationships at school, but negatively with more influence on decisions about school. Participation in political activities (such as party membership and candidacy) is related to more influence on decisions about school, while negatively to good student-relationships at school. Evidence is thus mixed for different measures of democratic participatory climate and different types of political participation. At the school level, we find only a positive relation between teachers' perception of a good classroom climate and electoral participation. No relations are found for teachers' and principals' perception of influence on decisions about school. Although there are some trends in the analysis future analyses should look more detailed into which aspects of a participatory school climate matter for specific forms of political participation, for instance interactions with gender (Barber and Torney-Purta 2009).

It has to be noted however that what matters most strongly is the individual perception of the student. The assessment made by teachers and principals of the participatory democratic climate at school most often does not have a significant effect. Clearly, students' intentions for political participation are influenced much more strongly by their own perception of a participatory democratic climate than by the perception of their teachers and principals. Although there is a positive correlation between the pupils' judgment and the opinion of the teacher, most of the time this correlation is rather weak and it situated somewhere at the $.20 / .30$ level. The conclusion to be drawn is that it matters whether students perceive the school climate to be participatory or not; the opinion of teachers and principals matters less in this regard. To some extent 
this might represent a measurement problem, as teachers and principals try to respond in a socially desired way about the climate at their school. Just as likely however, we can side with Ehman (1970) showing that what really matters is how the individual student perceives the participatory democratic climate at school.

The conclusion in any case has to be that different perceptions of the participatory democratic climate at school can coexist. What seems to matter most is the individual experience and perception of the student, not what happens at the aggregate level. Future research should therefore look into the different dimensions of a participatory democratic school climate, and measure these dimensions at different levels.

The main conclusion to be drawn, therefore, is that it does matter whether a student perceives his or her school as an participatory democratic environment where s/he can express opinions and ideas, and can engage in school policy. This individual level perception is associated with the intention to engage in political life later on. While the ICCS provides us with access to unique data about a host of countries, its limitation is that the data collection is purely cross-sectional. While the current study allows us to establish associations between both variables, it does not allow us to establish causality. One might claim that the school climate has an impact on the attitudes of pupils, but a reverse causal logic is also plausible, and more longitudinal observations are clearly required to gain more insight into the direction of causality. 
Bibliography

Ainley, J. and Schulz, W. (2011), 'Expected particpation in protest activites among lower secondary students in 38 countries', Paper prepared for the Annual Meetings of the American Educational Research Association in New Orleans, 8-12 April.

Almond, G. A. and Verba, S. (1963), The Civic Culture: political attitudes and democracy in five nations (Princeton: Princeton University Press).

Barber, C. and Torney-Purta, J. (2009), 'Gender differences in political attitudes and efficacy as influenced by national and school contexts', in D. Baker and A. Wiseman (eds.), Gender, equality, and education from international perspectives (Bingley: Emerald Group Publishing).

Benton, T., et al. (2009), Citizenship Education Longitudinal Study (CELS): Sixth Annual Report Young People's Civic Participation In and Beyond School: Attitudes, Intentions and Influences (London: National Foundation for Educational Research).

Campbell, D. E. (2006a), Why We Vote: How Schools and Communities Shape Our Civic Life (Princeton: Princeton University Press).

--- (2006b), 'Deliberation in the classroom: political discussion and adolescents' engagement. Working paper'.

--- (2008), 'Voice in the Classroom: How an Open Classroom Climate Fosters Political Engagement Among Adolescents', Political Behavior, 30 (4), 43754.

Campbell, D. E., Desjardins, R., and Schuller, T. (2006), What is Education's Impact on Civic and Social Engagement? (Paris: Centre for Educational Research and Innovation, Organization for Economic Cooperation and Development), 25-126.

Dalton, R. J. (2008), 'Citizenship Norms and the Expansion of Political Participation', Political Studies, 56, 76-98.

Dewey, J. (1913), The School and Society (Chicago: University of Chicago Press).

Eccles, J. S. and Roeser, R. W. (2011), 'Schools as Developmental Contexts During Adolescence', Journal of Research on Adolescence, 21 (2), 225-41.

Ehman, L. H. (1970), 'A Comparison of Three Sources of Classroom Data: Teachers, Students, and Systematic Observation. Paper presented at the annual meeting of the American Education Research Association, Minneapolis'.

--- (1980), 'Change in High School Students' Political Attitudes as a Function of Social Studies Classroom Climate', American Educational Research Journal 17 (2), 253-65.

Flanagan, C. A., et al. (2007), 'School and Community Climates and Civic Commitments: Patterns for Ethnic Minority and Majority Students', Journal of Educational Psychology, 99 (2), 421-31. 
Galston, W. A. (2007), 'Civic Knowledge, Civic Education, and Civic Engagement: A Summary of Recent Research', International Journal of Public Administration, 30 (6), 623-42.

Gibson, C. and Levine, P. (2003), The Civic Mission of Schools (New York: Carnegie Corporation and The Center for Information and Research on Civic Learning (CIRCLE)).

Gimpel, J. G., Lay, C. J., and Schuknecht, J. E. (2003), Cultivating Democracy. Civic Environments and Political Socialization in America (Washington, D.C.: Brookings Institution Press).

Gniewosz, B., Noack, P., and Buhl, M. (2009), 'Political alienation in adolescence: Associations with parental role models, parenting styles, and classroom climate', International Journal of Behavioral Development, 33 (4), 337-46.

Hahn, C. (1998), Becoming political: comparative perspectives on citizenship education (Albany: State University of New York Press).

Hess, D. E. (2009), Controversy in the Classroom: The Democratic Power of Discussion (New York: Routledge).

Hooghe, M. and Stolle, D. (2004), 'Good Girls Go to the Polling Booth, Bad Boys Go Everywhere: Gender Differences in Anticipated Political Participation Among American Fourteen-Year-Olds', Women and Politics, 26 (3/4), 1-23.

Hooghe, M. and Wilkenfeld, B. (2008), 'The Stability of Political Attitudes and behaviors across Adolescence and Early Adulthood. A Comparison of Survey Data on Adolescents and Young Adults in Eight Countries', Journal of Youth and Adolescence, 37 (2), 155-67.

Hox, J. (2002), Multilevel Analysis. Techniques and Applications (Mahwah, NJ: Lawrence Erlbaum).

Ichilov, O., et al. (2003), Education and Democratic Citizenship in a Changing World (Oxford: Oxford University Press), 636-69.

Jaros, D. (1973), Socialization to politics. Basic concepts in political science (Nairobi: Nelson).

Jennings, M. K. (2007), 'Political Socialization', in Russell J. Dalton and HansDieter Klingemann (eds.), Oxford Handbook of Political Behavior (Oxford: Oxford University Press), 29-44.

Kahne, J. E. and Sporte, S. E. (2008), 'Developing citizens: The impact of civic learning opportunities on students' commitment to civic participation', American Educational Research Journal, 45 (3), 738-66.

Lay, C. J. (2007), 'Smaller Isn't Always Better: School Size and School Participation Among Young People', Social Science Quarterly, 88 (3), 790-815.

Lindsay, P. (1984), 'High School Size, Participation on Activities, and Young Adult Social Participation: Some Enduring Effects of Schooling', Educational Evaluation and Policy Analysis, 6 (1), 73-83.

Marsh, D. (1971), 'Political Socialization: The Implicit Assumptions Questioned', British Journal of Political Science, 1 (4), 453-65.

McFarland, D. A. and Thomas, R. J. (2006), 'Bowling young: How youth voluntary associations influence adult political participation', American Sociological Review, 401-25. 
Niemi, R. G. and Junn, J. (1998), Civic education: What Makes Students Learn? (New Haven: Yale University Press).

Norris, P. (2011), Democratic Deficit (Cambridge: Cambridge University Press).

Quintelier, E. (2010), 'The effect of schools on political participation: a multilevel logistic analysis', Research Papers in Education, 25 (2), 137-54.

Schulz, W., Ainley, J., and Fraillon, J. (2011), ICCS 2009 Technical report (Amsterdam: International Association for the Evaluation of Educational Achievement).

Schulz, W., et al. (2010), Initial Findings from the IEA International Civic and Citizenship Education Study (Amsterdam: International Association for the Evaluation of Educational Achievement).

Sherrod, L. R., Torney-Purta, J., and Flanagan, C. A. (2010), 'Research on the Development of citizenship: A Field Comes of Age', in Lonnie R. Sherrod, Judith Torney-Purta, and Constance A. Flanagan (eds.), Handbook of Research on Civic Engagement in Youth (Hoboken: John Wiley \& Sons, Inc).

Tarrow, S. (2003), Power in Movement. Social Movements and Contentious Politics (2nd ed.) (Cambridge: Cambridge University Press).

Torney-Purta, J. (2002), 'The School's Role in developing Civic Engagement: A Study of Adolescents in Twenty-Eight Countries', Applied Developmental Science, 6 (4), 203-12.

Torney-Purta, J. and Vermeer, S. L. (2006), Developing Citizenship Competencies from Kintergarten through Grade 12: A Background Paper for Policymakers and Educators (Denver: Education Commissions of the States).

Torney-Purta, J., Oppenheim, A. N., and Farnen, R. F. (1975), Civic education in ten countries: An empirical study (New York: Wiley).

Torney-Purta, J., Barber, C. H., and Wilkenfeld, B. (2007), 'Latino Adolescents' Civic Development in the United States: Research Results from the IEA Civic Education Study', Journal of Youth and Adolescence, 36 (2), 111-25.

Torney-Purta, J., Wilkenfeld, B., and Barber, C. (2008), 'How Adolescents in 27 Countries Understand, Support, and Practice Human Rights', Journal of Social Issues, 4 (4), 857-80.

Torney-Purta, J., et al. (2001), Citizenship and education in twenty-eight countries: civic knowledge and engagement at age fourteen (Amsterdam: IEA).

Verba, S., Schlozman, K. L., and Brady, H. E. (1995), Voice and equality: civic voluntarism in American Politics (Cambridge: Harvard University Press).

Westheimer, J. and Kahne, J. (2004), 'Educating the 'Good' Citizen: Political Choices and Pedagogical Goals', PS: Political Science and Politics, 37 (2), 241-47.

Whiteley, P. (2005), Citizenship Education Longitudinal Study. Second Literature Review. Citizenship Education: The Political Science Perspective (Nottingham: National Foundation for Educational Research).

Youniss, J. (2011), 'Civic Education: What Schools Can Do to Encourage Civic Identity and Action', Applied Developmental Science, 15 (2), 98-103.

Youniss, J. and Levine, P. (2009), Engaging Young People in Civic Life (Nashville: Vanderbilt University Press). 


\section{Appendix 1: Variables used in the analysis}

\section{Level 1: Individual level variables}

\section{Dependent variables}

Legal protest

Electoral participation

Participation in political activities

Informal political participation

\section{Background variables}

Gender (1=girl)

Number of books at home

Expected years of further education

Control variables: students' ...

Citizenship self-efficacy

Trust in civic institutions

Sense of internal political efficacy

Interest in politics and social issues

Discussion of political and social issues

outside of school

Civic knowledge

Civic participation in the community

Open classroom climate: Students' perceptions of ...

Openness in classroom discussions

Influence on decisions about school

Student-teacher relationships at school
N Mean Std. Dev. Minimum Maximum

$\begin{array}{lllll}104972 & 50.12 & 10.06 & 19.19 & 79.45 \\ 104297 & 50.27 & 10.01 & 23.85 & 63.05 \\ 104124 & 50.06 & 10.18 & 29.85 & 75.47 \\ 103898 & 50.42 & 10.05 & 27.57 & 74.09\end{array}$

$\begin{array}{lllll}109013 & 0.51 & 0.5 & 0 & 1\end{array}$

$\begin{array}{lllll}108833 & 2.15 & 1.37 & 0 & 5\end{array}$

$\begin{array}{lllll}108024 & 6.37 & 2.23 & 0 & 9\end{array}$

$\begin{array}{lllll}105377 & 50.36 & 10.01 & 15.53 & 79.88\end{array}$

$\begin{array}{lllll}106311 & 50.01 & 9.99 & 20.21 & 77.35\end{array}$

$\begin{array}{lllll}107224 & 50.28 & 9.84 & 22.94 & 79.74\end{array}$

$\begin{array}{lllll}107340 & 50.46 & 9.88 & 26.58 & 73.81\end{array}$

$\begin{array}{lllll}107679 & 50.16 & 10.03 & 32.62 & 82.96\end{array}$

$\begin{array}{lllll}109784 & 499.65 & 99.73 & 127.82 & 885.96\end{array}$

$\begin{array}{lllll}107685 & 50.2 & 10.18 & 38.68 & 86.34\end{array}$

$\begin{array}{lllll}107786 & 49.97 & 10.11 & 14.83 & 78.98\end{array}$

$\begin{array}{lllll}107533 & 50.88 & 10.12 & 26.86 & 73.84\end{array}$

$\begin{array}{lllll}107899 & 50.37 & 9.98 & 17.62 & 73.53\end{array}$ 
Open classroom climate: teachers

N Mean Std. Dev. Minimum Maximum

perception of ...

Classroom climate (of student

relationships)

$\begin{array}{lllll}4210 & 50.13 & 5.05 & 23.09 & 63.46\end{array}$

Student's influence on decisions about

school

$\begin{array}{lllll}4210 & 49.76 & 5.69 & 24.56 & 74.45\end{array}$

Open classroom climate - principals'

perceptions of ...

Students' influence on decisions about

school

$\begin{array}{lllll}4210 & 50.75 & 9.8 & 19.5 & 75.27\end{array}$

School-level variables

School autonomy

Student-teacher ratio at school

$\begin{array}{llll}4210 & 51.06 & 8.92 & 7.16\end{array}$

80.15

School size $(* 1000)$

4210

15.19

$17.48 \quad 1.04$

454.2

4210

676.14

642.32

7702

\section{Intraclass correlation null-models}

\begin{tabular}{|c|c|c|c|c|}
\hline Students' expected adult & Legal protest & $\begin{array}{c}\text { Electoral } \\
\text { participation }\end{array}$ & $\begin{array}{c}\text { Participation in } \\
\text { political } \\
\text { activities }\end{array}$ & $\begin{array}{c}\text { Informal } \\
\text { political } \\
\text { participation }\end{array}$ \\
\hline Intraclass correlation Level 2 & 9.417 & 12.634 & 11.691 & 11.935 \\
\hline Intraclass correlation Level 3 & 6.315 & 6.632 & 7.770 & 8.929 \\
\hline
\end{tabular}


Appendix 2: Student's perception of participatory democratic climate, aggregated per school

\begin{tabular}{|c|c|c|c|c|c|c|c|c|c|c|c|c|}
\hline \multirow[t]{2}{*}{ Students' expected adult ... } & Le & l protes & & \multicolumn{2}{|c|}{ Electoral participation } & ation & \multicolumn{3}{|c|}{ Participation in } & $\begin{array}{r}\text { Infor } \\
\text { pa }\end{array}$ & Informal political & \\
\hline & $\mathrm{B}$ & SD & Sig. & $\mathrm{B}$ & $\mathrm{SD}$ & Sig. & $\mathrm{B}$ & $\mathrm{SD}$ & Sig. & $\mathrm{B}$ & $\mathrm{SD}$ & Sig. \\
\hline \multicolumn{13}{|c|}{ Students' perceptions of openness in classroom } \\
\hline discussions, aggregated per school & -0.017 & 0.018 & ns & 0.037 & 0.025 & ns & -0.041 & 0.018 & $*$ & -0.002 & 0.012 & ns \\
\hline \multicolumn{13}{|l|}{ Teachers perception of classroom climate of } \\
\hline student relationships & -0.012 & 0.008 & ns & 0.022 & 0.009 & $*$ & 0.016 & 0.009 & ns & -0.004 & 0.008 & ns \\
\hline \multicolumn{13}{|c|}{ Principals perception of students' influence on } \\
\hline decisions about school & 0.000 & 0.004 & ns & -0.001 & 0.004 & ns & -0.004 & 0.003 & ns & 0.001 & 0.003 & ns \\
\hline
\end{tabular}




\section{Appendix 3: Participatory democratic climate questions}

\section{Students' perception of particpatiory democratic climate}

1) Openness in classroom discussions (OPDISC)

2) Influence on decisions about school (STUDINF)

3) Student-teacher relationships at school (STUTREL)
When discussing political and social issues during regular lessons, how often do the following things happen?

Teachers encourage students to make up their own minds

Teachers encourage students to express their opinions Students bring up current political events for discussion in class

Students express opinions in class even when their opinions are different from most of the other students

Teachers encourage students to discuss the issues with people having different

In this school, how much is your opinion taken into account when decisions are made

about the following issues?

The way classes are taught

What is taught in classes

Teaching and learning materials

The timetable

Classroom rules

School rules

How much do you agree or disagree with the

following statements about you and your school?

Most of my teachers treat me fairly

Students get along well with most teachers

Most teachers are interested in students' well-being -

Most of my teachers really listen to what I have to say

If I need extra help, I will receive it from my teachers

Teachers' perception of participatory democratic climate:

1) Classroom climate (TCLCLIM) of student relationships

2) Student's influence on decisions about school (TSTUDINF)
Teachers' perceptions of classroom climate In your opinion, how many of your <target grade> students ... get on well with their classmates? are well integrated in the class? respect their classmates even if they are different? have a good relationship with other students?

At this school, how much are students' opinions taken into account when decisions are made about the following issues?

Teaching/learning materials 
The timetable

Classroom rules

School rules

Principals' perception of participatory democratic climate

Students' influence on decisions about school (CSTUDINF)

In this school, how much are students' opinions taken into account when decisions are made about the following issues?

Teaching/learning materials

The timetable

Classroom rules

School rules 


\section{Appendix 4: wording for the control variables}

Background variables

Gender (1=girl)

Number of books at home

Expected years of further education

Control variables: students' ...

Citizenship selfefficacy

Trust in civic institutions

Sense of internal political efficacy

Interest in politics and social issues
Are you a girl or a boy?

About how many books are there in your home?

There are usually about 40 books per metre of shelving. Do not count magazines, newspapers, comic strips or your schoolbooks. (Please tick only one box)

0-10 books; 11-25 books; 26-100 books; 101-200 books; 201-500 books; More than 500 books.

Which of the following <levels of education> do you expect to complete? (Please tick only one box)

$<$ ISCED level 5A or 6>; <ISCED level 4 or 5B > ; $\langle$ ISCED level 3>; $<$ ISCED level 2> ; I do not expect to complete; <ISCED level 2> (inversely coded)

How well do you think you would do the following activities? Discuss a newspaper article about a conflict between countries Argue your point of view about a controversial political or social issue

Stand as a candidate in a <school election>

Organise a group of students in order to achieve changes at school Follow a television debate about a controversial issue

Write a letter to a newspaper giving your view on a current issue Speak in front of your class about a social or political issue

How much do you trust each of the following institutions?

The <national government $>$ of < country of test>

The <local government $>$ of your town or city

Courts of justice

The police

Political parties

$<$ National Parliament>

How much do you agree or disagree with the following statements about you and politics?

I know more about politics than most people my age

When political issues or problems are being discussed, I usually have something to say I am able to understand most political issues easily I have political opinions worth listening to

As an adult I will be able to take part in politics

I have a good understanding of the political issues facing this country

How much are you interested in the following issues?

Political issues within your <local community>

Political issues in your country

Social issues in your country

Politics in other countries

International politics

Discussion of political How often are you involved in each of the following activities and social issues

outside of school? 
outside of school

Civic knowledge

Civic participation in the community
Talking with your parent(s) about political or social issues Talking with friends about political and social issues

Talking with your parent(s) about what is happening in other countries

Talking with friends about what is happening in other countries For the calculating of the civic knowledge scores, see: Schulz, W., Ainley, J. \& Fraillon, J. (Eds) (2011). ICCS 2009 technical report. Amsterdam, The Netherlands: International Association for the Evaluation of Educational Achievement (IEA).

Have you ever been involved in activities of any of the following organisations, clubs or groups?

Youth organisation affiliated with a political party or union Environmental organisation

Human Rights organisation

A voluntary group doing something to help the community An organisation collecting money for a social cause A cultural organisation based on ethnicity

A group of young people campaigning for an issue 


\section{Endnotes}

1. Originally, the ICCS dataset included information from 38 countries. However, The Netherlands and Greece did not provide school and/or teacher data. Additionally, Liechtenstein did not provide information on some school level-variables (student-teacher ratio and school size). These countries are therefore left out for the analyses, leaving us with data from 35 countries to analyze: Austria, Belgium (Flemish), Bulgaria, Chile, Chinese Taipei, Colombia, Cyprus, Czech Republic, Denmark, Dominican Republic, England, Estonia, Finland, Guatemala, Hong Kong SAR, Indonesia, Ireland, Italy, Korea, Latvia, Lithuania, Luxembourg, Malta, Mexico, New Zealand, Norway, Paraguay, Poland, Russian Federation, Slovak Republic, Slovenia, Spain, Sweden, Switzerland, and Thailand.

2. However, Gniewosz, Noack and Buhl (2009) found no effect of class-level open classroom climate ('I encourage students to make up their own minds about issues and to express them') on political alienation.

3. The ICCS 2009 International Database provides five separate estimates of each student's score on civic knowledge. These civic knowledge scales are already negatively correlated without any control variables. All 5 scales produce the same results. The negative relation is thus not the result of a measurement artifact.

4. These effects remain the same if we do not aggregate the results per school but use individual measures of teachers. This might suggest that teachers do not just give their perception about what goes on in their own class, but rather about the general interaction climate at their school. 